\title{
Role of umbilical artery Doppler velocimetry in predicting the adverse perinatal outcomes in hypertensive disorder of pregnancy
}

\author{
Jyoti Yadav ${ }^{1 *}$, Mala Shukla², P. K. Jain ${ }^{3}$, Devender Kumar ${ }^{4}$
}

\begin{abstract}
${ }^{1}$ Department of Obstetrics and Gynecology, Esic Medical Collage, Basaidarapur, Delhi, India ${ }^{2}$ Department of Obstetrics and Gynecology, ${ }^{3}$ Department of Radiology, Hindu Rao Hospital, Delhi ${ }^{4}$ Department of Anaesthesia and Critical Care, AIIMS, Delhi, India
\end{abstract}

Received: 11 July 2017

Revised: 05 August 2017

Accepted: 18 August 2017

\section{*Correspondence:}

Dr. Jyoti Yadav,

E-mail: devender0511@yahoo.in

Copyright: $\odot$ the author(s), publisher and licensee Medip Academy. This is an open-access article distributed under the terms of the Creative Commons Attribution Non-Commercial License, which permits unrestricted non-commercial use, distribution, and reproduction in any medium, provided the original work is properly cited.

\section{ABSTRACT}

Background: Early detection of fetoplacental compromise with Umbilical Artery Doppler indices and to know the predictive value of each indices in predicting perinatal outcome and interventional strategies in these patients.

Methods: The present prospective study was conducted on 200 women with hypertensive disorder of pregnancy. Umbilical artery doppler evaluation done in all the patients at (28-32) weeks, (33-36) weeks and (37-40) weeks of gestation and more frequently in those patients having deranged Doppler. Patients divided into two groups women with abnormal Umbilical artery indices (group B) and normal indices (group A). Perinatal outcome of both the groups were compared, analyzed statistically using Chi-square test. Multiple pregnancy, chronic hypertension, fetal congenital anomalies, systemic disease and those lost to follow up till delivery were excluded from study.

Results: A total of 200 pregnant women with hypertensive disorder, $64 \%$ were primgravida. Abnormal umbilical artery indices seen in $36 \%$. Adverse outcome was seen in $88.88 \%$ patients of group B. Statistically significantly higher rate of caeserian section, induction of labour, Preterm delivery, fetal growth restriction, NICU admission, NICU stay >48hrs were seen in group B. In all indices Umbilical artery PI had highest Sensitivity (84.21\%), positive predictive value $(88.88 \%)$ and accuracy $(90 \%)$.

Conclusions: Umbilical artery PI is the most reliable to predict adverse perinatal outcomes and help in appropriate timing of intervention to improve perinatal outcome.

Keywords: Hypertensive disorders, Perinatal adverse outcomes, Sensitivity, Umbilical artery doppler indices

\section{INTRODUCTION}

Pregnancy entails risks. Risk grading in pregnancy is a vital tool for maternal and fetal monitoring. Hypertensive disorders of pregnancy are one of the major causes of maternal morbidity-mortality leading to $10-15 \%$ of maternal deaths especially in developing areas of the world. ${ }^{1}$ It affects $5-10 \%$ of pregnancies and is principally a disease of primigravidas. ${ }^{2}$ Hypertension in pregnancy is also responsible for $18 \%$ of fetal (more than 19 weeks of gestation) and infant mortality as well as $46 \%$ of infant born small for gestation age. ${ }^{3}$

The Perinatal complications includes preterm birth, FGR babies, oligohydramnios, placental abruption, fetal hypoxia, non reassuring fetal status and perinatal death.

Predicting the risk of these complications may improve the outcome by providing appropriate antenatal surveillance and therapeutic interventions. 
The traditional methods of fetal surveillance like nonstress test, fetal heart monitoring and fetal biophysical profile are no more ideal tests because of their inability to detect early stages of fetal distress, significant number of false positive tests and low predictive value. Doppler examination makes it possible by providing a unique, non invasive and safe method of studying blood flow characteristics in both the fetoplacental and uteroplacental circulations that is being used in clinical evaluation of high risk pregnancies.

UA Doppler velocimetry is the most evaluated test among non-invasive tests of foetal well being. ${ }^{4} \mathrm{~A}$ meta analysis of randomized controlled trials of UA Doppler velocimetry (2013) in high risk pregnancies (mainly pregnancies associated with hypertension and suspected IUGR) demonstrated that its use was associated with a trend toward reduction in perinatal mortality, although there was no effect on neonatal morbidity. ${ }^{5}$

Present study is an effort to establishing the role of UA Doppler ultrasound in predicting adverse perinatal outcome in hypertensive disorders of pregnancy and to determine its role in clinical management of such pregnancies.

Objectives of present study were early detection of fetoplacental compromise in hypertensive disorder of pregnzancy with Umbilical artery indices (Resistance index , pulsatality index and systolic/diastolic ratio) and to know the predictive power of each indices of UA doppler in predicting the perinatal outcome and interventional strategies

\section{METHODS}

The present prospective study "Role of umbilical artery Doppler velocimetry in predicting the adverse perinatal outcomes in hypertensive disorder of pregnancy" was undertaken in the Department of Obstetrics and Gynecology in Hindu Rao Hospital for one and half year after getting clearance by the Ethical Committee of our institution.

Two hundred women with hypertensive disorder of pregnancy at 28-40 weeks attending ANC OPD were included in the study. After informed consent women were evaluated with umbilical artery doppler indices at (28-32) weeks, (33-36) weeks and (37-40) weeks of gestation and more frequently in those patients who were clinically indicated to determine a favorable or a worsening trend in the Doppler indices. Findings of last Doppler examination were taken into consideration. After last Doppler study, these women divided into two groups Study GP (women with abnormal UA indices) and Control GP (women with normal UA Doppler Indices). Perinatal outcome of both the groups were compared to find out predictive values of different indices (PI, RI, S/D) of umbilical artery Doppler velocimetry.

\section{Inclusion criteria}

- Any garvida with singleton pregnancy

- Diagnosed cases hypertensive disorder of pregnancy

- Women with POG 28-40 weeks.

\section{Exclusion criteria}

- Multiple gestations

- Systemic diseases like Chronic hypertension, chronic renal disease, SLE

- Fetal congenital anomalies

- $\quad$ lost to follow up till delivery.

The instrument used was Philips HD 11XE Color Doppler ultrasound machine with a convex transducer of 3.5 MHz frequency. The early fetoplacental compromise can be detected by deranged umbilical artery doppler indices. The UA S/D, PI, RI ratios were considered abnormal if the value were above the 95th percentile of previously published values for gestational age. 6

The women followed throughout pregnancy, delivery and early puerperium. Perinatal outcome measured include.

- Type of labor onset-Spontaneous or Induced

- Mode of delivery-Normal or LSCS

- Gestation at the time of delivery

- Fetal growth restriction

- Meconium aspiration syndrome

- Low apgar score

- NICU admissions

- IUD, Still birth and neonatal death.

The predictive power of different indices of umbilical artery Doppler velocimetry for adverse pregnancy perinatal outcomes was expressed by sensitivity, specificity, positive predictive value (PPV), negative predictive value (NPV) and accuracy.

\section{Statistical analysis}

Data were entered into a personal computer and analysed using SPSS version 20.0 computer software. $\chi^{2}$ - test was used for categorical data. And the $\mathrm{P}<0.05$ were considered to be statistically significant.

\section{RESULTS}

During the study period, a total 200 women with hypertensive disorder of pregnancy were recruited, studied and their results were analysed. Out of 200, maximum women 96 (48\%) were within 25-30 yrs of age group. And mean \pm SD age was $26.9 \pm 4.140 y$ rs. Mostly $128(64 \%)$ women were primigravida. According to prepregnancy BMI 48(24\%) women were overweight and $76(38 \%)$ were obese. Only $38(19 \%)$ women in the study having family history or history of hypertensive disorder 
in previous pregnancy. Rest $81 \%$ were not having any significant history.

Table 1: Distribution on the basis of types of hypertensive disorders.

\begin{tabular}{|c|c|c|}
\hline Types of hypertensive disorders & $\begin{array}{l}\text { No. of } \\
\text { patients }\end{array}$ & $\%$ \\
\hline GHTN & 96 & 48 \\
\hline Pre eclampsia with non severe features & 78 & 39 \\
\hline Pre eclampsia with severe features & 26 & 13 \\
\hline
\end{tabular}

While classifying hypertensive disorder of pregnancy according to the new ACOG 2013 classification we found $96(48 \%)$ women with GHTN,78 (39\%) women presented with preeclampsia with non severe features and $26(13 \%)$ were having preeclampsia with severe features (Table 1).

Table 2: Distribution on the basis of umbilical artery Doppler waveform.

\begin{tabular}{|lll|}
\hline Doppler waveform & No. of \\
patients
\end{tabular}

After last Doppler evaluation in all the hypertensive women, we found $72(36 \%)$ women were having abnormal umbilical artery doppler indices, they form study group and 128 (64\%) with normal Doppler were grouped as control group (Table 2).

Table 3: Distribution on the basis of pregnancy outcomes.

\begin{tabular}{|l|ll|}
\hline $\begin{array}{l}\text { Pregnancy } \\
\text { outcome }\end{array}$ & $\begin{array}{l}\text { Normal } \\
\text { umbilical artery } \\
\text { doppler indices }\end{array}$ & $\begin{array}{l}\text { Abnormal } \\
\text { umbilical artery } \\
\text { doppler indices }\end{array}$ \\
\hline Adverse & $12(10.34 \%)$ & $64(88.88 \%)$ \\
\hline Uneventful & $116(90.62 \%)$ & $8(11.11 \%)$ \\
\hline Total & 128 & 72 \\
\hline
\end{tabular}

Adverse outcomes were seen in $64(88.88 \%)$ women with abnormal UA doppler and $12(10.34 \%)$ women with normal UA Doppler. Perinatal outcomes were uneventful in $8(11.11 \%)$ women with abnormal UA doppler and 116 $(90.62 \%)$ women with normal UA Doppler (Table 3$)$.

Table 4: Distribution of abnormal umbilical artery doppler waveform.

\begin{tabular}{|lll|}
$\begin{array}{l}\text { Umbilical A. } \\
\text { indices }\end{array}$ & $\begin{array}{l}\text { No. of patients with } \\
\text { abnormal umbilical } \\
\text { artery doppler indices }\end{array}$ & $\begin{array}{l}\text { Adverse } \\
\text { outcomes }\end{array}$ \\
\hline Umbilical A. PI & 72 & $64(88.88 \%)$ \\
\hline Umbilical A. RI & 63 & $46(73 \%)$ \\
\hline Umbilical A. S/D & 65 & $50(76.92 \%)$ \\
\hline
\end{tabular}

It was observed that out of 72 women with abnormal UA PI 64 (88.88\%) were having adverse perinatal outcomes and out of 65 women with abnormal UA S/D 50 $(76.92 \%)$ were having poor perinatal outcomes lastly 63 women with abnormal UA RI, 46 (73\%) were having adverse perinatal outcomes (Table 4 ).

Table 5: Distribution on the basis of perinatal mortality.

\begin{tabular}{|lll|}
\hline & $\begin{array}{l}\text { No. of } \\
\text { patients }\end{array}$ & $\begin{array}{l}\text { Perinatal } \\
\text { mortality }\end{array}$ \\
\hline $\begin{array}{l}\text { Absent end diastolic flow } \\
\text { (AEDF) }\end{array}$ & $3(4.16 \%)$ & $2(66.66 \%)$ \\
\hline $\begin{array}{l}\text { Reverse end diastolic flow } \\
\text { (REDF) }\end{array}$ & $1(1.38 \%)$ & $1(100 \%)$ \\
\hline
\end{tabular}

Out of 72 women with abnormal Doppler 3 had AEDF with $66.66 \%$ perinatal mortality and 1 had REDF with $100 \%$ mortality (Table 5).

Table 6: Distribution on the basis of mode of delivery.

\begin{tabular}{|c|c|c|c|}
\hline \multirow[b]{2}{*}{$\begin{array}{l}\text { Mode of } \\
\text { delivery }\end{array}$} & \multicolumn{3}{|c|}{ Doppler waveform } \\
\hline & $\begin{array}{l}\text { Normal } \\
\text { umbilical } \\
\text { artery Doppler } \\
\text { indices }\end{array}$ & $\begin{array}{l}\text { Abnormal } \\
\text { umbilical } \\
\text { artery Doppler } \\
\text { indices }\end{array}$ & \multirow{2}{*}{$\begin{array}{l}\mathrm{X}^{2}= \\
8.32\end{array}$} \\
\hline Vaginal & $86(67.18 \%)$ & $34(47.22 \%)$ & \\
\hline $\begin{array}{l}\text { Elective } \\
\text { LSCS }\end{array}$ & $12(9.37 \%)$ & $14(19.44 \%)$ & \multirow{3}{*}{$\begin{array}{l}\mathrm{P}< \\
0.016\end{array}$} \\
\hline $\begin{array}{l}\text { Emergency } \\
\text { LSCS }\end{array}$ & $30(23.43 \%)$ & $24(33.33 \%)$ & \\
\hline Total & 128 & 72 & \\
\hline
\end{tabular}

It was found that $38(52.77 \%)$ women in abnormal doppler group delivered by caeserian where as caeseran rate in normal UA Doppler group was 42 (33\%). There was statistically significant $(\mathrm{p}<0.016)$ difference in caeseran rate of the both groups (Table 6).

Table 7: Distribution on the basis of gestational age at the time of delivery.

\begin{tabular}{|l|l|l|}
\hline $\begin{array}{l}\text { Gestational age } \\
\text { at delivery } \\
\text { (weeks) }\end{array}$ & $\begin{array}{l}\text { Normal } \\
\text { umbilical artery } \\
\text { doppler indices }\end{array}$ & $\begin{array}{l}\text { Abnormal } \\
\text { umbilical artery } \\
\text { doppler indices }\end{array}$ \\
\hline $28-32$ & $2(1.56 \%)$ & $4(5.55 \%)$ \\
\hline $32-34$ & $12(9.37 \%)$ & $16(22.22 \%)$ \\
\hline $34-36$ & $36(28.12 \%)$ & $27(37.5 \%)$ \\
\hline$\geq 37$ & $78(60.93 \%)$ & $25(34.72 \%)$ \\
\hline Total & 128 & 72 \\
\hline Mean \pm sd & $37.46 \pm 1.28$ weeks & $35.2 \pm 1.95$ weeks \\
\hline
\end{tabular}

Mean gestational age at delivery was $34.2 \pm 1.95$ weeks in women with abnormal Doppler while it was $37.46 \pm 1.28$ weeks in normal Doppler group. $37.5 \%$ in study group were late preterm delivery and $28 \%$ delivered $<34$ weeks while in control group $28 \%$ delivered babies were late preterm and only $11 \%$ delivered before 34 weeks (Table 7). 
Table 8: Doppler velocimetry of umbilical artery and perinatal outcomes.

\begin{tabular}{|lllll|}
\hline Perinatal outcome & $\begin{array}{l}\text { Normal umbilical artery } \\
\text { Doppler indices }\end{array}$ & $\begin{array}{l}\text { Abnormal umbilical } \\
\text { artery Doppler indices }\end{array}$ & $\begin{array}{l}\text { Chi square } \\
\text { test }\end{array}$ & $\begin{array}{l}\text { P } \\
\text { value }\end{array}$ \\
\hline Induced labour & $40(31.25 \%)$ & $44(61.11 \%)$ & 15.663 & 0.0001 \\
\hline LSCS & $42(32.81 \%)$ & $38(52.77 \%)$ & 6.84 & 0.0089 \\
\hline Preterm & $50(39.06 \%)$ & $47(65.27 \%)$ & 11.64 & 0.0006 \\
\hline Fetal growth restriction & $21(16.40 \%)$ & $23(31.94 \%)$ & 5.612 & 0.0178 \\
\hline AP $<7$ AT 5 min & $18(14.06 \%)$ & $17(23.61 \%)$ & 2.28 & 0.130 \\
\hline NICU admission & $23(17.96 \%)$ & $24(33.33 \%)$ & 5.23 & 0.022 \\
\hline NICU stay $>$ 48 hrs & $7(5.46 \%)$ & $15(20.83 \%)$ & 9.61 & 0.0019 \\
\hline Meconium aspiration syndrome & $6(4.68 \%)$ & $5(6.94 \%)$ & 0.123 & 0.7263 \\
\hline IUD & 0 & $2(2.77 \%)$ & 1.32 & 0.249 \\
\hline Early neonatal death & $1(0.78 \%)$ & $3(4.16 \%)$ & 1.24 & 0.265 \\
\hline
\end{tabular}

It was observed that in (Table 8) there were statistically significant difference in FGR $31.94 \%$ vs $16.40 \%$ $\mathrm{p}=0.0178)$, NICU admissions $(33.33 \%$ vs $17.96 \%$ p $=0.002)$, NICU stay $>48 \mathrm{hrs}(20.83 \%$ vs $5.46 \% \mathrm{p}=0.0019)$ in the study group and control group respectively. More babies $(23.61 \%)$ were born with low APGAR score and Meconium aspiration syndrome $(6.94 \%)$ in the study group as compared to control group $14.06 \%$ and $4.68 \%$ respectively. But the difference was not statistically significant. In study group 2 babies were died in utero at 30 weeks of gestation and 3 babies in early neonatal period because prematurity and meconium aspiration syndrome while in control group no in utero death seen but one baby died in early neonatal period.

Table 9: Diagnostic index of umbilical artery parameters as predictor of adverse perinatal outcomes.

\begin{tabular}{|c|c|c|c|c|c|}
\hline $\begin{array}{l}\text { Umbilical artery } \\
\text { Doppler indices }\end{array}$ & Sensitivity & $\begin{array}{l}\text { Positive predictive } \\
\text { value }\end{array}$ & Specificity & $\begin{array}{l}\text { Negative predictive } \\
\text { value }\end{array}$ & Accuracy \\
\hline $\mathrm{Pi}$ & 84.21 & 88.88 & 93.54 & 90.62 & 90 \\
\hline $\mathrm{Ri}$ & 77.35 & 73 & 87.21 & 90.62 & 85.5 \\
\hline $\mathrm{S} / \mathrm{d}$ & 80.64 & 76.92 & 88.54 & 90.62 & 86.5 \\
\hline
\end{tabular}

Table 10: No. of patients with umbilical artery Doppler indices.

\begin{tabular}{lllll}
$\begin{array}{l}\text { Umbilical } \\
\text { artery } \\
\text { Doppler } \\
\text { indices }\end{array}$ & $\begin{array}{l}\text { True } \\
\text { positive }\end{array}$ & $\begin{array}{l}\text { False } \\
\text { negative }\end{array}$ & $\begin{array}{l}\text { False } \\
\text { positive }\end{array}$ & $\begin{array}{l}\text { True } \\
\text { negative }\end{array}$ \\
\hline PI & 64 & 12 & 8 & 116 \\
\hline RI & 46 & 12 & 17 & 125 \\
\hline S/D & 50 & 12 & 15 & 123 \\
\hline
\end{tabular}

In this study, we found that UA PI had highest predictive power with sensitivity $(84.21 \%)$, PPV $(88.88 \%)$ and accuracy (90\%) followed by UA S/D having sensitivity (80.64\%), PPV (76.92\%) and accuracy (86.5\%). Specificity and negative predictive power was same for all the UA indices.

\section{DISCUSSION}

Hypertensive disorder of pregnancy is a common cause of feto-maternal mortality affecting 5-10\% of pregnant women and is associated with $22 \%$ perinatal deaths.
Doppler studies in high-risk pregnancies are more beneficial in the management of perinatal and neonatal outcomes. $^{7-9}$

Hypertension in pregnancy affects women of all ages. In the current study, maximum number of patients were in the 26-30yrs age. Parazzini et al also reported the increased incidence of preeclamsia with age. ${ }^{10}$

We found maximum women $(64 \%)$ in our study were primigravida. The immunologic theory supports that hypertension is most commonly a disease of $1^{\text {st }}$ pregnancy. Khalid et al study showed $77.77 \%$ patients in preeclampsia were primigravida. ${ }^{11}$ Mendez et al in their study also reported, $36.9 \%$ women were primigravida with PE. ${ }^{12}$

Pre pregnancy BMI is an independent risk factor for $\mathrm{PIH}$ and their adverse effect. In the current study, 24\% women were overweight and $38 \%$ women were obese. Asim et al found that pregnancy induced hypertension was two times more likely in obese women than non-obese women. ${ }^{13}$ Based on $24 \mathrm{hrs}$ urine protein test, laboratory 
investigations and sign and symptoms preeclampsia, we found 96 (48\%) women with GHTN,78 (39\%) women presented with preeclampsia with non severe features and $26(13 \%)$ were having preeclampsia with severe features.

After last Doppler evaluation, we found out of 200 women with hypertensive disorder $72(36 \%)$ were having abnormal umbilical artery doppler indices, they form study group and 128 (64\%) with normal Doppler study grouped as control group.

Table 11: Prevalence of abnormal doppler in hypertensive women in present study and reference studies.

\begin{tabular}{|ll|l|}
\hline Author & Abnormal Doppler & Normal Doppler \\
\hline Bhatt et al & $56 \%$ & $44 \%$ \\
\hline Gupta et al & $55 \%$ & $45 \%$ \\
\hline Srilakshmi et al & $68 \%$ & $32 \%$ \\
\hline Present Study & $36 \%$ & $64 \%$ \\
\hline
\end{tabular}

Prevalence of abnormal doppler in hypertensive women in Present study and reference studies is given in Table $11 . .^{14-16}$

On individualizing the indices of umbilical artery Doppler we found 72 women with abnormal UA PI and abnormal UA S/D and UA RI were identified in 65 and 63 women respectively. Adverse outcome were seen in $88.88 \%$ of women in abnormal Doppler group and only $10.34 \%$ in normal Doppler group.

In abnormal Doppler group $41.66 \%$ women underwent for induction of labour and in normal Doppler group $21.87 \%$ required induction of labour, difference was statistically significant $\left(\mathrm{p}<0.001 \chi^{2}=16.90\right)$. Smitha et al also reported more induction rate in hypertensive patients with abnormal Doppler waveform. ${ }^{17}$

There was statistically significant difference $\left(\mathrm{p}<0.016 \chi^{2}\right.$ $=8.32$ ) in caesarean rate of the both groups. It was seen that $52.77 \%$ women in abnormal Doppler group and $32.81 \%$ in normal Doppler group delivered by caesarean. Sharma et al. (2010) had a $78 \%$ caesarean delivery rate in PIH patients with abnormal Doppler. ${ }^{18}$

In study group mean gestational age at delivery was $35.2 \pm 1.95$ weeks while in control group it was $37.46 \pm 1.28$ wks. Khalid et al noted 37.44 weeks and 38.69 weeks mean gestational age at the time of delivery in study group and control group respectively. ${ }^{11}$

It was observed that there was statistically significant difference in FGR (31.94\% vs $16.40 \%$ p=0.0178), NICU admissions $(33.33 \%$ vs $17.96 \% \mathrm{p}=0.002)$, NICU stay $>48 \mathrm{hrs}(20.83 \%$ vs $5.46 \% \mathrm{p}=0.0019)$ in the study group and control group respectively.

More babies were born with Low APGAR score $(23.61 \%)$ and Meconium aspiration syndrome $(6.94 \%)$ in the study group as compared to control group $14.06 \%$ and $4.68 \%$ respectively. But the difference was not statistically significant.

In study group 2 babies were died in utero at 30 weeks of gestation and 3 babies in early neonatal period because prematurity and meconium aspiration syndrome while in control group no in utero death seen but one baby died in early neonatal period.

Smitha et al reported low APGAR score in $34.7 \%$, NICU admission in $45.65 \%$, IUD in $21.74 \%$ and perinatal death in $6.52 \%$ with abnormal umbilical artery flow in PIH group. ${ }^{17}$

Srilakshmi et al were noted $70 \%$ LBW, $48 \%$ preterm deliveries, $38 \%$ NICU admission and $16 \%$ neonate with less apgar score in study group with abnormal umbilical artery flow. ${ }^{16}$

In our study, out of 72 abnormal Doppler flows, 3 patients had absent diastolic flow and one had reversal of flow in umbilical artery. Two babies with AEDF were died in early neonatal period because of prematurity. Thus, a high perinatal mortality of $66.66 \%$ was noted with AEDF. One patient with reversed diastolic flow, baby was died in utreo at 30 weeks. $100 \%$ perinatal mortality noted in patients with REDF.

The current study has shown that absent or reversed end diastolic flow in the umbilical artery was strongly associated with major perinatal morbidity with mortality. This has been well recognized in the literature that there is strict correlation between the abnormal UA and poor perinatal outcome.

Table 12: Various studies of time and absent and reversed diastolic flow in the umbilical artery is associated with high perinatal mortality and morbidity.

\begin{tabular}{|lll|}
\hline Author (Year) & $\begin{array}{l}\text { Mortality in } \\
\%(\text { AEDF) }\end{array}$ & $\begin{array}{l}\text { Mortality in } \\
\%(\text { REDF })\end{array}$ \\
\hline Bhatt et al & $50 \%$ & $50 \%$ \\
\hline Lakhar et al & $100 \%$ & $100 \%$ \\
\hline Smitha et al & $27.78 \%$ & $100 \%$ \\
\hline Srilakhshmi et al & $100 \%$ & $100 \%$ \\
\hline Padmini CP et al & $75 \%$ & $100 \%$ \\
\hline Present study & $66.66 \%$ & $100 \%$ \\
\hline
\end{tabular}

In Table 12, many researchers have shown, time and again that absent and reversed diastolic flow in the umbilical artery is associated with high perinatal mortality and morbidity. ${ }^{16,17}$, $19-21$

In present study, we observed that in all the indices of UA Doppler wave from UA PI had highest sensitivity $(84.21 \%)$, positive predictive power $(88.88 \%)$ and accuracy (90\%) followed by UA S/D waveform with sensitivity (80.64\%), PPV (76.92\%) and accuracy 
$(86.5 \%)$. Specificity and negative predictive power were almost same for all the UA indices. Various studies showing (Table 13) the predictive value of umbilical artery in predicting the adverse pregnancy outcome. ${ }^{17,20,22-24}$

Table 13: Various studies of the predictive value of umbilical artery in predicting the adverse pregnancy outcome.

\begin{tabular}{|lllllll|}
\hline Author & Index & SS & SP & PPV & NPV & Accuracy \\
\hline Yoon et al & PI & $89 \%$ & $86.0 \%$ & $86.0 \%$ & $89.0 \%$ & \\
\hline Ozeren et al & PI & $69 \%$ & $97 \%$ & $95 \%$ & $81.0 \%$ & \\
\hline Smitha et al & PI & $90.26 \%$ & $80.57 \%$ & $82.24 \%$ & $88.35 \%$ & $62 \%$ \\
\hline \multirow{3}{*}{ Goyal et al } & PI & $41.30 \%$ & $50 \%$ & $83.33 \%$ & $41.37 \%$ & $76 \%$ \\
& S/D & $65.21 \%$ & $57.4 \%$ & $83.33 \%$ & $33.33 \%$ & $64 \%$ \\
\hline \multirow{3}{*}{ Lakhar et al } & RI & $45.65 \%$ & $78.57 \%$ & $87.5 \%$ & $23.91 \%$ & $56.8 \%$ \\
& PI & $58 \%$ & $56.5 \%$ & $35 \%$ & $86.8 \%$ & $48 \%$ \\
\hline \multirow{3}{*}{ Present study } & S/D & $75 \%$ & $41.3 \%$ & $25 \%$ & $86.3 \%$ & $68.9 \%$ \\
& RI & $58 \%$ & $71.7 \%$ & $35 \%$ & $86.8 \%$ & 90 \\
\hline
\end{tabular}

Meta-analysis from the Cochrane database syst Rev 2013 showed the use of Doppler ultrasound in high-risk pregnancy was associated with a reduction in perinatal deaths (risk ratio (RR) $0.71,95 \%$ confidence interval (CI) 0.52 to 0.98 . There were also fewer inductions of labour and fewer caesarean sections. ${ }^{5}$

\section{CONCLUSION}

The following conclusions were drawn after the study.

- Significant association seen with abnormal UA indices and adverse perinatal outcomes.

- Doppler velocimetry has proved to reliably detect early fetoplacental compromise in hypertensive pregnancies and can be an useful tool for taking decision in the appropriate timing of intervention for delivery thereby reducing perinatal morbidity and mortality

- Out of all indices UA PI had highest sensitivity, PPV and good accuracy with less false positive rates in managing high risk pregnancy.

Funding: No funding sources

Conflict of interest: None declared

Ethical approval: The study was approved by the Institutional Ethics Committee

\section{REFERENCES}

1. Yücesoy G, Özkan S, Bodur H, Tan T, Çalışkan E, Vural B, Çorakçı A. Maternal and perinatal outcome in pregnancies complicated with hypertensive disorder of pregnancy: a seven year experience of a tertiary care center. Arch Gynecol Obstet. 2005;273(1):43-9.
2. Cunningham FG, Kenneth J, Leveno, Steven L, Bloom, Spong CY, Dashe JS, Hoffman BL et al. Williams Obstetrics, 24th ed. New York, New York: McGraw-Hill Co;2014:746-758.

3. Montan S, Sjoberg O, Svenningsen N. Hypertension in pregnancy-fetal and infant outcome. Clin Exp Hypertens: Hyper in Pregnancy. 1987;B62:337-48.

4. Fitzgerald DE, Drumm JE. Non-invasive measurement of human fetal circulation using ultrasound: a new method. BMJ. 1977;2:1450-1.

5. Alfirevic Z, Stampalija T, Gyte GM. Fetal and umbilical Doppler ultrasound in high-risk pregnancies. Cochrane Database Syst Rev. 2013;(11):CD007529.

6. Ozeren M, Dinc H, Ekmen U, Senakayli C, Aydemir V. Umbilical and middle cerebral artery Doppler indices in patients with preeclampsia. Eur J Obstet Gynaecol Reprod Biol. 1999;82(1):11-6.

7. Low JA. The current status of maternal and fetal velocimetry. Am J Obstet Gynecol. 1991;164:104963.

8. Imdad A, Yakoob MY, Siddiqui S, Bhutta ZA. Screening and triage of intrauterine growth restriction (IUGR) in general population and high risk pregnancies: A systematic review with a focus on reduction of IUGR related stillbirths. BMC Public Health. 2011;11 Suppl 3:S1

9. Hoffman C, Galan HL. Assessing the 'at-risk' fetus: Doppler ultrasound. Curr Opin Obstet Gynecol. 2009;21:161-6.

10. Parazzini F, Bortolus R, Chatenoud L, Restelli S, Ricci E, Marozio L et al. Risk factors for pregnancyinduced hypertension in women at high risk for the condition. Epidemiology. 1996;7(3):306-8.

11. Khalid M, Wahab S, Kumar V, Khalid S, Haroon S, Sabzposh NA. Doppler indices in prediction of fetal 
outcome in hypertensive pregnant women. NJOG. 2011;6(1):28-34.

12. Lopez-Mendez MA, Martinez-Gaytan V, CortesFlores R, Ramos-Gonzalez RM, Ochoa-Torres MA, Garza-Veloz I et al. Doppler ultrasound evaluation in preeclampsia. BMC Res Notes. 2013;6(1):477.

13. Asim SS, Naeem H. Pregnancy with obesity: a risk factor for PIH. JLUMHS. 2010;09(03):125-9.

14. Bhatt CJ, Arora J, Shah MS. Role of color doppler in pregnancy induced hypertension (a study of 100 cases). Indian J Radiol Imaging. 2003;13:417-20.

15. Gupta S. Comparison of foetomaternal circulation in normal pregnancies and pregnancy induced hypertension using color doppler studies. Indian J Physiol Pharmacol. 2014;58(3):284-9.

16. Srilakshmi KN, Raghavendra AA. Study of triple vessel wave pattern by doppler studies in low risk and high risk pregnancies and perinatal outcome. JEMDS. 2014;3(46):11160-6.

17. Smitha K, Sowmya K, Malathi T. Study of Doppler waveforms in pregnancy induced hypertension and its correlation with perinatal outcome. Int J Reprod Contracept Obstet Gynecol. 2014;3(2):428-33.

18. Sharma U, Bhatnagar B. Triple vessel wave pattern by Doppler studies in normal and high risk pregnancies and perinatal outcome. J Obstet Gynecol India. 2010;60(4):312-6.

19. Bhatt CJ, Arora J, Shah MS. Role of color doppler in pregnancy induced hypertension (a study of 100 cases). Indian J Radiol Imaging. 2003;13:417-20.
20. Lakhar BN, Ahamed SA. Doppler velocimetry of uterine and umbilical arteries during pregnancy. Ind $\mathbf{J}$ Radiol Imag. 1999;9(3):119-125.

21. Padmini CP, Das P, Chaitra RM, Adithya S. Role of Doppler indices of umbilical and middle cerebral artery in prediction of perinatal outcome in preeclampsia. Int $\mathbf{J}$ Reprod Contracept Obstet Gynecol. 2016;5:845-9.

22. Yoon BH, Lee CM, Kim W. An abnormal umbilical artery wave form: A strong and independent predictor of adverse per/natal outcome in patients with pre-eclampsia. Am J Obstet Gynecol. 1994;173:713-21.

23. Ozeren M, Dinc H, Ekmen U, Senakayli C, Aydemir V. Umbilical and middle cerebral artery Doppler indices in patients with preeclampsia. Eur J Obstet Gynaecol Reprod Biol. 1999;82(1):11-6.

24. Goyal S, Maheshwari S. Clinical Utility of Colour Doppler for Diagnosis of Adverse Perinatal Outcome in IUGR and PIH. Natl J Med Dental Res. 2014;2(4):48.

Cite this article as: Yadav J, Shukla M, Jain PK, Kumar D. Role of umbilical artery Doppler velocimetry in predicting the adverse perinatal outcomes in hypertensive disorder of pregnancy. Int $\mathbf{J}$ Reprod Contracept Obstet Gynecol 2017;6:4382-8. 